\title{
Multidrug-Resistant Bacteria Isolated from Surface Water in Bassaseachic Falls National Park, Mexico
}

\author{
Ma. Carmen E. Delgado-Gardea ${ }^{1,2}$, Patricia Tamez-Guerra ${ }^{1}$, Ricardo Gomez-Flores ${ }^{1}$, \\ Francisco Javier Zavala-Díaz de la Serna ${ }^{2}$, Gilberto Eroza-de la Vega ${ }^{2}$, \\ Guadalupe Virginia Nevárez-Moorillón ${ }^{2}$, María Concepción Pérez-Recoder ${ }^{3}$, \\ Blanca Sánchez-Ramírez ${ }^{2}$, María del Carmen González-Horta ${ }^{2}$ and Rocío Infante-Ramírez ${ }^{2, *}$ \\ 1 Departamento de Microbiología e Inmunología, Facultad de Ciencias Biológicas, \\ Universidad Autónoma de Nuevo León Ave. Universidad s/n, San Nicolás de los Garza 66450, N.L., Mexico; \\ carmen_060@hotmail.com (M.C.E.D.-G.); patamez@hotmail.com (P.T.-G.); rgomez60@hotmail.com (R.G.-F.) \\ 2 Laboratorio de Biotecnología, Facultad de Ciencias Químicas, Universidad Autónoma de Chihuahua, \\ Circuito Nuevo Campus Universitario s/n, Chihuahua 31125, Mexico; fzavala@uach.mx (F.J.Z.-D.S.); \\ gerosa@uach.mx (G.E.-V.); vnevare@uach.mx (G.V.N.-M.); bsanche@uach.mx (B.S.-R.); \\ carmengonzalez@uach (M.C.G.-H.) \\ 3 Comisión Nacional de Áreas Naturales Protegidas, Dirección Regional Norte y Sierra Madre Occidental, \\ Parque Nacional Cascada de Bassaseachic, Ocampo, Chihuahua 31203, Mexico; crecoder@conanp.gob.mx \\ * Correspondence: rir_infante@yahoo.com.mx; Tel.: +52-(614)-236-6000 (ext. 4265)
}

Academic Editor: Paul B. Tchounwou

Received: 4 May 2016; Accepted: 7 June 2016; Published: 16 June 2016

\begin{abstract}
Bacterial pathogens are a leading cause of waterborne disease, and may result in gastrointestinal outbreaks worldwide. Inhabitants of the Bassaseachic Falls National Park in Chihuahua, Mexico show seasonal gastroenteritis problems. This aim of this study was to detect enteropathogenic microorganisms responsible for diarrheal outbreaks in this area. In 2013, 49 surface water samples from 13 selected sampling sites along the Basaseachi waterfall and its main rivers, were collected during the spring, summer, autumn, and winter seasons. Fecal and total coliform counts were determined using standard methods; the AutoScan-4 system was used for identification of isolates and the antibiotic resistance profile by challenging each organism using 21 antibiotics. Significant differences among seasons were detected, where autumn samples resulted in the highest total $(p<0.05)$ and fecal $(p<0.001)$ coliform counts, whereas the lowest total coliform counts were recorded in spring. Significant differences between sampling sites were observed, where samples from sites 6,8 , and 11 had the highest total coliform counts $(p<0.009)$, whereas samples from site 9 exhibited the lowest one. From the microbiological analysis, 33 bacterial isolates from 13 different sites and four sampling seasons were selected; $53 \%$ of isolates were resistant to at least one antibiotic, and 15\% exhibited a multidrug resistance (MDB) phenotype. MDB were identified as Klebsiella oxytoca (two out of four identified isolates), Escherichia coli (2/7), and Enterobacter cloacae (1/3). In addition, some water-borne microorganisms exhibited resistance to cefazoline, cefuroxime, ampicillin, and ampicillin-sulbactam. The presence of these microorganisms near rural settlements suggests that wastewater is the contamination source, providing one possible transmission mechanism for diarrheal outbreaks.
\end{abstract}

Keywords: water; pollution; antibiotic; multidrug resistance; enteric; microorganisms; MPN; environment

\section{Introduction}

Bacteria are one of the most important pathogens in waterborne diseases, and these organisms cause gastrointestinal outbreaks worldwide. Many human diseases are transmitted as a result of the ingestion of contaminated water and food. There are nearly 1.7 billion cases of diarrhea per 
year worldwide; this condition is the second leading cause of death in children less than five years old [1-3] and kills nearly 760,000 children per year. These health problems are common in rural areas in developing countries, which lack access to safe, fresh drinking water, and they remain a serious problem [4,5]. Enteric bacteria are present in the human gastrointestinal system and feces of all warm-blooded animals. These bacteria are commonly dumped into water environments through the runoff from farms and rural settlements with industrial and agricultural pollutants, lacking of wastewater treatment systems $[1,6]$.

Bacterial pathogens potentially transmitted through water ingestion include Escherichia coli, Klebsiella sp., Salmonella enterica subsp. Enterica Serovar Typhi, Salmonella enterica subsp. Enterica Serovar Paratyphi, Shigella spp., Vibrio cholerae, Acinetobacter sp., Clostridium spp., and Bacillus anthracis. Other bacterial pathogens that can survive in soil and water include Legionella, Burkholderia pseudomallei (also known as Pseudomonas pseudomallei), and atypical mycobacteria [1,2,5]. Since 1895, E. coli has been identified as an indicator of fecal pollution in water samples; not all species of $E$. coli are pathogenic, but a few of these bacteria, such as E. coli O157:H7, can be fatal [7,8]. The most probable number technique is commonly used as an index to determine the microbial safety of drinking water; this method is performed in multiple tubes showing the probabilistic value of the bacteria in $100 \mathrm{~mL}$ of water, as described in ISO 6461 [9].

Untreated waste introduces additional resistant bacteria into water, likely also constituting an important mechanism for the dissemination of antibiotic-resistant bacteria (ARBs) in natural bacterial communities. ARBs are becoming a major global public health problem [10,11], and the extensive use of antimicrobial treatments in humans and animals may increase resistant bacterial populations in the aquatic environment [12]. Most antibiotic resistance research has focused on isolates from clinical patients, but ARBs are widespread in the environment, including water and soil [11]. In 2013, Bassaseachic Falls National Park in Chihuahua presented diarrhea outbreaks among inhabitants of the park, primarily in children, probably caused by contaminated water consumption. The aim of the present study was to identify the multidrug-resistant enteric pathogenic and native bacteria present in the surface water of Bassaseachic Falls National Park in Chihuahua, Mexico as a possible source of water outbreaks.

\section{Experimental Section}

\subsection{Sample Collection}

Thirteen reference locations situated near rural settlements, waterfall wells, and the belvedere used by inhabitants to collect water for drinking, cooking or washing purposes, were selected in the Bassaseachic Falls National Park, Ocampo Municipality in the state of Chihuahua, Mexico $\left(28^{\circ} 07^{\prime} 59^{\prime \prime} \mathrm{N}\right.$ $108^{\circ} 15^{\prime} 00^{\prime \prime} \mathrm{W}$, Figure 1).

A total of 49 sampling points were selected from 13 different points described in Table 1, and each location was selected near principal rural settlements. Samples 1,2, and 13 refer directly to Basaseachi Falls; in addition, two samples were collected from the visitors' center (sample 9) and a small waterfall (sample 2) next to the Basaseachi waterfall. Four 1-L samples were collected at each location using 1.2-L polypropylene bottles previously sterilized under UV light for $3 \mathrm{~h}$, according to Mexican sampling standards [13]). Each sample was collected approximately $30 \mathrm{~cm}$ below the water surface, and the bottles were open only under the water. Four liters of water from each sampling point was stored upright on ice in 1.2-L polypropylene bottles until further laboratory analysis. The seasons were defined as winter (December), spring (March), summer (June) and autumn (October). Two of the total water samples were lost as a result of the dry spell during the summer (samples 5 and 6), and one water sample was lost during the spring as a result of unsafe sampling conditions (sample 13). All collection sites were identified using GPS (Table 1). The presence of native and enteropathogenic bacteria was determined using microbiological and biochemical techniques for the identification of Gram-negative bacteria from all collected samples. 


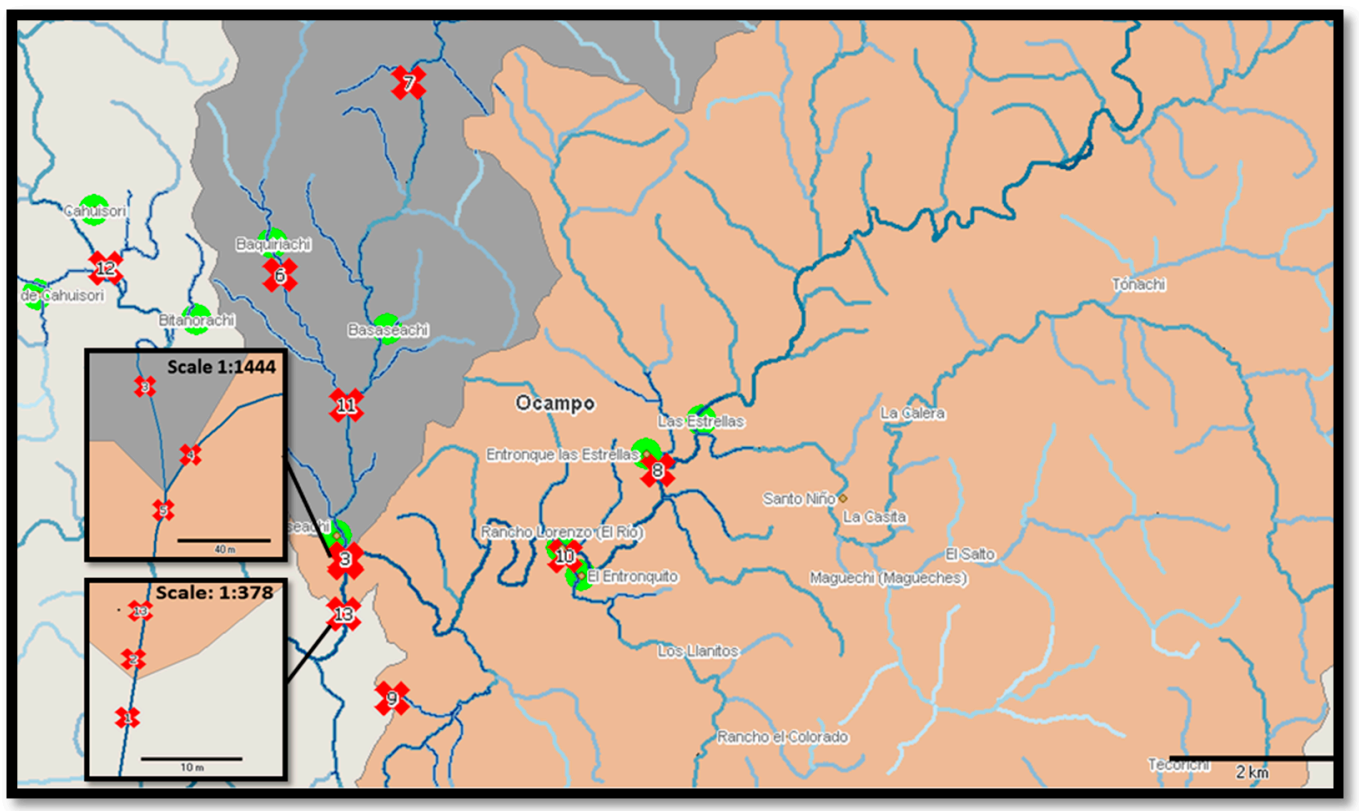

Figure 1. General scheme of Bassaseachic Falls National Park. The (X) symbols indicate the sampling sites: (๑) Rural settlement within the studied area. Source: INEGI digital map, Cartographic Package 2010; Scale 1:64140. Samples $5\left(28^{\circ} 10^{\prime} 47.45^{\prime \prime} \mathrm{N}, 108^{\circ} 12^{\prime} 45.49^{\prime \prime} \mathrm{W}\right)$ and $6\left(28^{\circ} 12^{\prime} 40.80^{\prime \prime} \mathrm{N}\right.$, $\left.108^{\circ} 13^{\prime} 20.49^{\prime \prime} \mathrm{W}\right)$ were lost during the summer, and sample 13 was lost during the spring $\left(28^{\circ} 10^{\prime} 27.36^{\prime \prime} \mathrm{N}\right.$, $\left.108^{\circ} 12^{\prime} 44.97^{\prime \prime} \mathrm{W}\right)$.

Table 1. Description of the freshwater sample sites at Bassaseachic Falls National Park during 2013.

\begin{tabular}{cccc}
\hline & Sample Points & \multicolumn{2}{c}{ Geographical Coordinates } \\
\hline Sample & Sample Site & North (N) & West (W) \\
\hline 1 & Basaseachi waterfall well & $28^{\circ} 10^{\prime} 26.95^{\prime \prime} \mathrm{N}$ & $108^{\circ} 12^{\prime} 44.99^{\prime \prime} \mathrm{W}$ \\
2 & "La ventana" waterfall & $28^{\circ} 10^{\prime} 27.17^{\prime \prime} \mathrm{N}$ & $108^{\circ} 12^{\prime} 44.88^{\prime \prime} \mathrm{W}$ \\
3 & "El Durazno" river & $28^{\circ} 10^{\prime} 48.24^{\prime \prime} \mathrm{N}$ & $108^{\circ} 12^{\prime} 45.09^{\prime \prime} \mathrm{W}$ \\
4 & Basaseachi river & $28^{\circ} 10^{\prime} 49.19^{\prime \prime} \mathrm{N}$ & $108^{\circ} 12^{\prime} 45.86^{\prime \prime} \mathrm{W}$ \\
5 & Y. Basaseachi junction of the river and Durazno river. & $28^{\circ} 10^{\prime} 47.45^{\prime \prime} \mathrm{N}$ & $108^{\circ} 12^{\prime} 45.49^{\prime \prime} \mathrm{W}$ \\
6 & "Baquiriachi" stream & $28^{\circ} 12^{\prime} 40.80^{\prime \prime} \mathrm{N}$ & $108^{\circ} 13^{\prime} 20.49^{\prime \prime} \mathrm{W}$ \\
7 & Basaseachi water supply stream & $28^{\circ} 13^{\prime} 59.55^{\prime \prime} \mathrm{N}$ & $108^{\circ} 12^{\prime} 26.07^{\prime \prime} \mathrm{W}$ \\
8 & "Las Estrellas" stream & $28^{\circ} 11^{\prime} 30.06^{\prime \prime} \mathrm{N}$ & $108^{\circ} 10^{\prime} 27.09^{\prime \prime} \mathrm{W}$ \\
9 & "Betorachi" stream & $28^{\circ} 09^{\prime} 54.7^{\prime \prime} \mathrm{N}$ & $108^{\circ} 12^{\prime} 21.7^{\prime \prime} \mathrm{W}$ \\
10 & Visitors center of Bassaseachic Falls National Park & $28^{\circ} 10^{\prime} 54.08^{\prime \prime} \mathrm{N}$ & $108^{\circ} 11^{\prime} 6.84^{\prime \prime} \mathrm{W}$ \\
11 & "Breek next to the oxidation pond & $28^{\circ} 11^{\prime} 50.25^{\prime \prime} \mathrm{N}$ & $108^{\circ} 12^{\prime} 47.88^{\prime \prime} \mathrm{W}$ \\
12 & "Cahuisori" stream & $28^{\circ} 12^{\prime} 40.58^{\prime \prime} \mathrm{N}$ & $108^{\circ} 14^{\prime} 38.92^{\prime \prime} \mathrm{W}$ \\
13 & Belvedere of Basaseachi waterfall & $28^{\circ} 10^{\prime} 27.36^{\prime \prime} \mathrm{N}$ & $108^{\circ} 12^{\prime} 44.97^{\prime \prime} \mathrm{W}$ \\
\hline
\end{tabular}

\subsection{Microbiological Analysis}

\subsubsection{Total/Fecal Coliform Determination}

Total and fecal coliform counts were determined using the multiple-tube fermentation technique and were reported as the most probable number (MPN) of organisms present per $100 \mathrm{~mL}$ of sample. The MPN analysis was performed within $24 \mathrm{~h}$ of sampling, according to the Mexican Standard [14]. Briefly, 10-, 1-, and 0.1-mL aliquots of the season/site samples were inoculated in triplicate into $10 \mathrm{~mL}$ of lactose broth (Merck, Naucalpan de Juárez, México) in an inverted Durham tube and incubated at $37^{\circ} \mathrm{C}$ for $24 \mathrm{~h}$; gas formation indicated a positive result. One milliliter of the gas-positive samples was inoculated into $10 \mathrm{~mL}$ of standard broth for total coliform counts and was incubated at $44^{\circ} \mathrm{C}$. Another milliliter of the gas-positive sample was inoculated in brilliant green broth for fecal coliform 
confirmation and was incubated at $37^{\circ} \mathrm{C}$. The negative samples were incubated for an additional $48 \mathrm{~h}$ as a confirmative test.

\subsubsection{Microbial Isolation}

Water samples that exceeded the Mexican Standard (1000 MPN/100 mL) were analyzed using standard microbiological techniques for the enumeration of bacteria and the identification of pathogens. To isolate pure cultures, the freshwater samples were placed in pre-selection media, followed by selective media (Supplementary Material Figure S1). From the initial bacterial growth, pure culture isolates were separated and analyzed further through macroscopic and microscopic characterizations. Each isolate was characterized based on its colony macroscopic morphology (shape, size, type of edge, transmitted or reflected light) and Gram stain. For isolation, the method of Al-Bayatti et al. [15] was followed, with minor modifications. Briefly, to obtain pure cultures, $10 \mathrm{~mL}$ of freshwater sample was inoculated into $10 \mathrm{~mL}$ of BBL-buffered peptone water (Difco, supplied by Productos Químicos Viqmar, Tlalnepantla Estado de México, México), 2\% sodium chloride broth (Sigma-Aldrich, St. Louis, MO, USA), tetrathionate broth (Difco) and selenite broth (Difco). The cultures were incubated overnight at $37^{\circ} \mathrm{C}$ using an oven (model 314, Thermo Fisher Scientific, Waltham, MA, USA), and $10 \mathrm{~mL}$ of the freshwater sample was also inoculated into nutrient broth (MCD Lab, Tlalnepantla, Estado de México, México) and incubated overnight at $42{ }^{\circ} \mathrm{C}$. The bacteria grown on selenite and tetrathionate broth as an original source were re-inoculated in Salmonella-Shigella (SS) to recover Salmonella and Shigella isolates (SS, Bioxon supplied by Productos Químicos Viqmar) and were incubated overnight at $37^{\circ} \mathrm{C}$. Bacteria grown in BBL-buffered peptone water and $2 \% \mathrm{NaCl}$ broth were re-inoculated onto thiosulfate citrate bile salt sucrose agar (TCBS, BD Bioxon, Estado de México, México) to recover a variety of Vibrio spp. [16]. In addition to nutrient broth, the samples were re-inoculated onto nutrient agar to increase the range of the recovered Gram-negative bacteria and onto MacConkey agar to presumptively identify the Escherichia coli isolates. The purified colonies were subsequently cultured on MacConkey agar and TCBS for further analysis and stored at $-20^{\circ} \mathrm{C}$ in trypticase soy broth (Bioxon) containing $30 \%$ glycerol.

\subsection{Biochemical Identification}

Pure colonies were recovered from MacConkey and TCBS agar for biochemical identification using the AutoSCAN-4 system (DADE Behring MicroScan-Plus, Kennett Square, PA, USA) to identify fermentative and non-fermentative Gram-negative bacilli. The AutoScan ID panel was prepared according to the manufacturer's instructions. Identification was based on the detection of $\mathrm{pH}$ changes determined via modified and chromogenic tests, substrate utilization, and growth in the presence of antimicrobial agents after $16-42 \mathrm{~h}$ of incubation at $35^{\circ} \mathrm{C}$. Rapid Combo panel NEG-44 was selected to identify Gram-negative bacteria based on conventional and chromogenic tests in 96-well microplates and on 27 dehydrated substrates. The results were analyzed using Labpro software to identify microorganisms and to generate an antibiotic resistance profile. Only Gram negative bacteria were further analyzed. Similarly, only one isolate from isolates showing similar macroscopic (colonial) and microscopic characteristic was selected.

\subsection{Antibiotic Resistance Analyses}

The antimicrobial susceptibility tests are miniaturizations of the broth dilution susceptibility test, using dehydrated samples. Pure colonies tested for biochemical identification were also tested to growth in the presence of antimicrobial agents for antibiotic resistance profiling using the AutoSCAN-4 system. The rapid combo panel NEG-44-tested antibiotics included: amikacin, ampicillin-sulbactam, ampicillin, aztreonam, cefazolin, cefepime, cefotetan, ceftazimide, ceftriaxone, cefuroxime, ciprofloxacin, gentamicin, imipenem, levofloxacin, meropenem, moxifloxacin, piperacillin-tazobactam, ticarcillin-clavulanic acid, tobramycin, and trimethoprim-sulfamethoxazole. The breakpoint combo panels used concentrations equivalent to the categorical breakpoints of the 
CLSI, and the minimum inhibitory concentrations (MICs) $[17,18]$. If two or more isolates from the same sampling point exhibited identical results according to the microscan biotype flinging number, then only one of the isolates was analyzed further.

\subsection{Statistical Analysis}

For the MPN analysis, the data were normalized through the logarithmic transformation of the quantitative MPN results, and ANOVA with the general linear model was used to test for determinations of statistical significance. Comparisons among groups were obtained using Tukey test. Minitab statistical software was used for data analysis. For each season, the calculation of the geometric mean included all sites, whereas the calculation of the geometric mean for each site included all seasons, with confidence intervals of 95\% (Minitab v17).

\section{Results}

\subsection{Microbiological Analysis}

The samples collected from Bassaseachic Falls National Park during 2013 were analyzed for total and fecal coliform enumeration. Results showed that calculated data were exceeding Mexican standards among total and fecal coliform counts. The total coliform counts from the sampling season and sampling sites are shown in Figure 2A. Similarly, the fecal coliform counts from the sampling season and sampling sites are shown in Figure 2B. The samples collected at site 9 showed the lowest total and fecal coliform counts compared with the other sample sites.
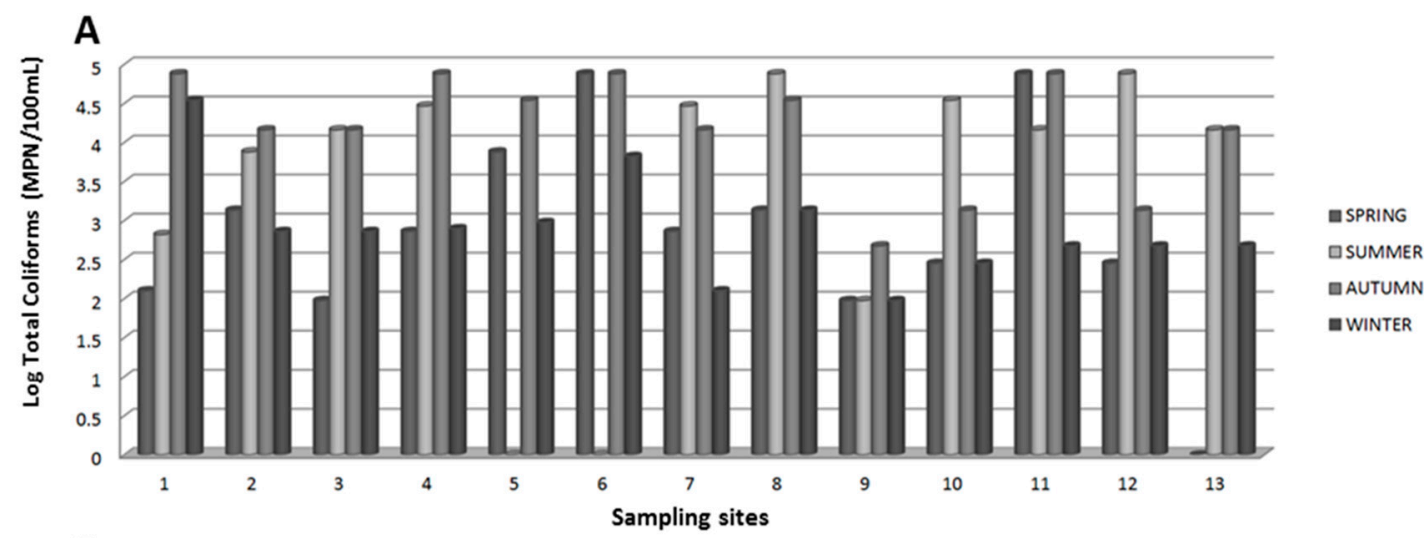

\section{B}

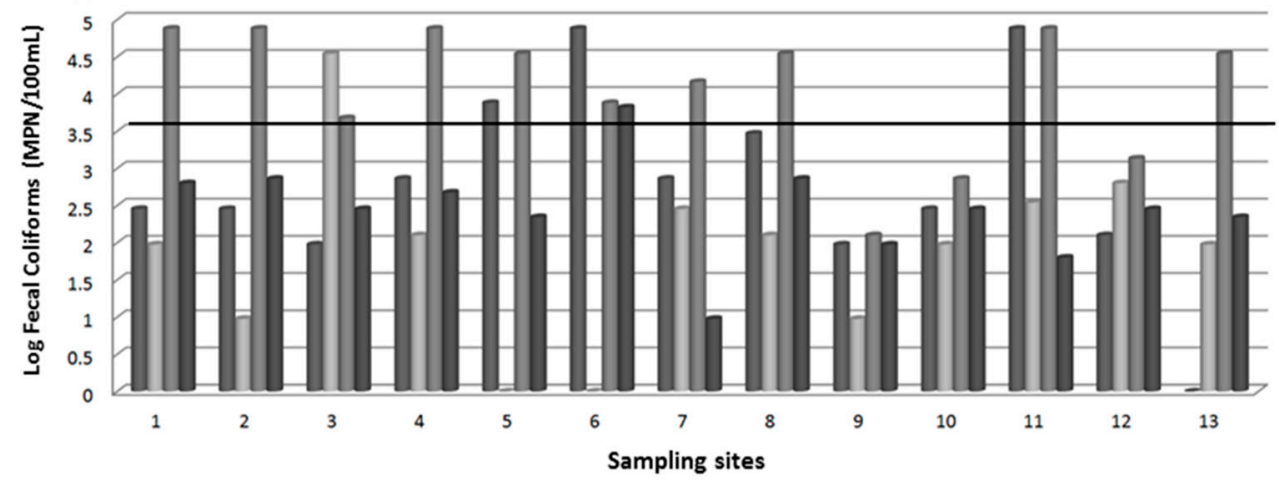

$=$ SPRING

\#SUMMER

$=$ AUTUMN

- WINTER

Figure 2. Log MPN counts of (A) total coliforms and (B) fecal coliforms per sampling site in the water samples collected from Bassaseachic Falls National Park, Ocampo, Chihuahua, México, during 2013. The black line across Figure 2B on 3.5 MPN indicates the [19].

In contrast, the samples collected from sites 5, 6, 8, and 11 exhibited the highest counts, where the total coliforms were higher than the fecal coliforms. Except for samples 9, 10 and 12, the collected 
water samples had greater than $1000 \mathrm{MPN} / 100 \mathrm{~mL}$ (3.5 MPN) fecal coliforms during the autumn and summer seasons.

The pooled MPN geometric mean was used to calculate the intervals, with a $95 \%$ confidence interval (Figure 3). The total coliform counts are shown in Figure 3A,B. ANOVA revealed significant differences $(p<0.001)$ between the total coliform counts from the autumn and summer (highest) and spring and summer (lowest) seasons. ANOVA also revealed significant differences between the total coliforms $(p<0.05)$ at the sampling sites. The results of Tukey test revealed that samples 6,8 , and 11 had the highest coliform counts and that sample 9 had the lowest count (Figure 3B).

A

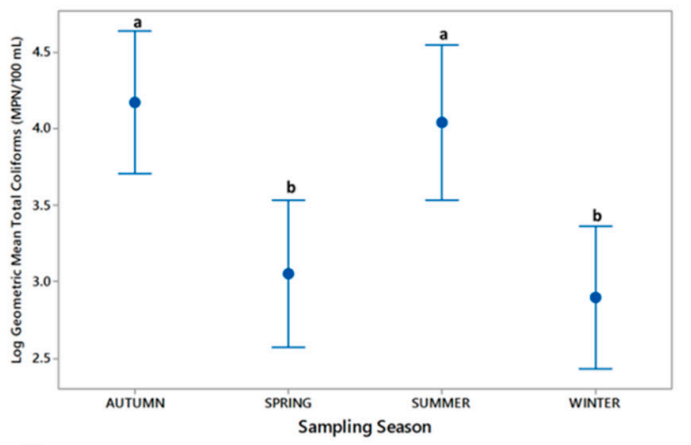

C

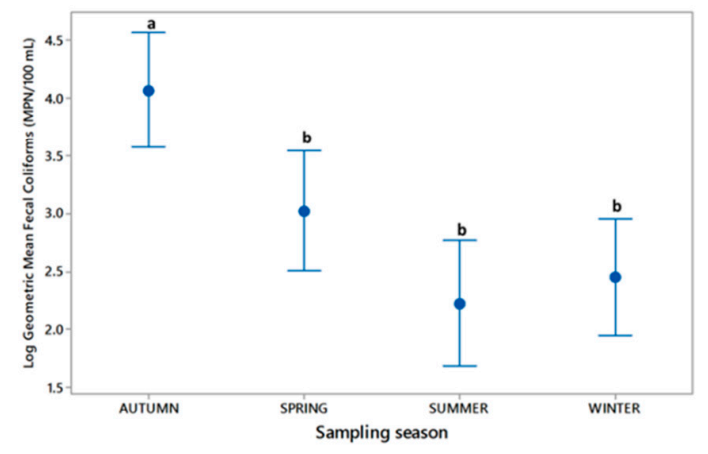

B

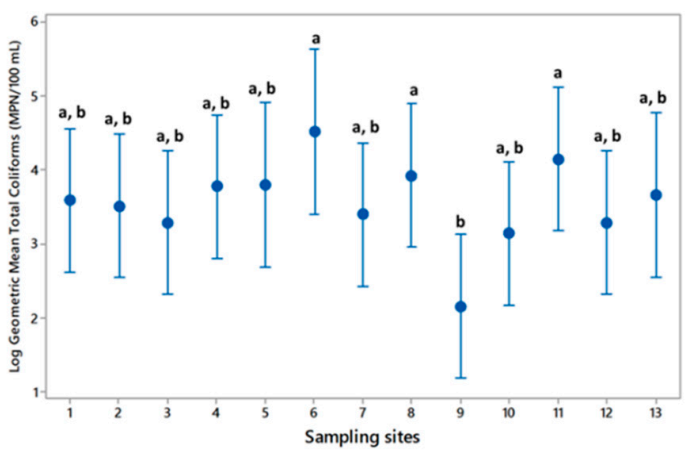

D

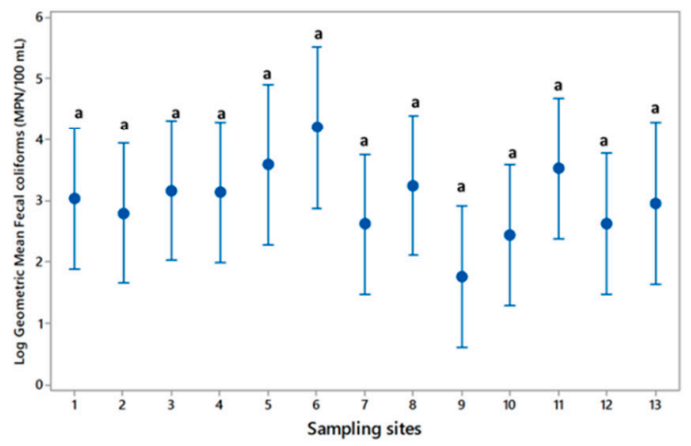

Figure 3. The geometric means considering all sites and all seasons in logarithmic scale and with confidence intervals of $95 \%$. (A) Total coliforms per sampling season; (B) Total coliforms per sampling site; (C) Fecal coliforms per sampling season; (D) Fecal coliforms per sampling site. Bars showing different letter are significantly different (Tukey, $p<0.05$ ).

The geometric mean of the fecal coliforms significantly varied among the seasons $(p<0.001)$, where most of the samples collected during autumn exhibited significant differences compared with the remaining samples collected during the 2013 seasons by Tukey test $(p<0.05)$ (Figure 3C). Tukey test also revealed no significant differences between the fecal coliform geometric means of the sampling sites from pooled seasons ( $p=0.133$; Figure 3D).

\subsection{Biochemical and Antibiotic Resistance Profiles}

A total of 33 Gram negative isolates showing different macroscopic and microscopic characteristics were recovered from 23 river water samples. The 33 bacterial isolates were selected for biochemical identification and to determine their antibiotic resistance profile. Results revealed that all 33 belonged to gammaproteobacteria, whereas the AutoScan-4 analysis revealed 16 different Gram-negative genera and species. Isolates were identified as belonging to the Enterobacteriaceae, Pasterurellaceae, Vibrionaceae, and Moraxellaceae families (Table 2). 
Table 2. Identified bacterial isolates recovered from freshwater at Bassaseachic Falls National Park during 2013.

\begin{tabular}{|c|c|c|c|c|}
\hline Family & $\begin{array}{l}\text { Isolate Identification and } \\
\text { References }^{1}\end{array}$ & $\begin{array}{l}\text { Number of } \\
\text { Isolates }\end{array}$ & $\begin{array}{l}\text { Sampling } \\
\text { Site }\end{array}$ & Sampling Season \\
\hline \multirow{12}{*}{ Enterobacteriaceae } & $\begin{array}{c}\text { Aeromonas hydrophila (Chester) } \\
\text { Stanier [20] }\end{array}$ & 1 & 3 & Autumn \\
\hline & $\begin{array}{l}\text { Citrobacter freundii Werkman \& } \\
\text { Gillen }[21,22]\end{array}$ & 2 & 2,5 & Summer-Winter \\
\hline & $\begin{array}{c}\text { Enterobacter cloacae } \\
\text { Jordan/Hormaeche [21] }\end{array}$ & 3 & $1,3,6$ & Autumn-Winter \\
\hline & Escherichia coli Escherich [21] & 7 & $1,6,11,13$ & Spring-Summer-Autumn-Winter \\
\hline & Hafnia alvei Møller [22] & 3 & $1,2,3$ & Summer-Autumn \\
\hline & $\begin{array}{l}\text { Klebsiella oxytoca } \\
\text { Flügge/Lautrop [21] }\end{array}$ & 4 & $1,8,10,11$ & Spring-Summer \\
\hline & Klebsiella pneumoniae Uber [21] & 1 & 11 & Summer \\
\hline & Salmonella spp. [23] & 1 & 5 & Autumn \\
\hline & $\begin{array}{c}\text { Salmonella enterica subsp. enterica } \\
\text { serovar Paratyphi A } \\
\text { (Ex Kauffmann \& Edwards) } \\
\text { Le Minor \& Popoff }[21,23]\end{array}$ & 2 & 1,12 & Spring-Winter \\
\hline & $\begin{array}{l}\text { Shigella sp. Castellani \& } \\
\text { Chalmers [21] }\end{array}$ & 1 & 13 & Spring \\
\hline & Tatumella sp. Hollis et al. [24] & 1 & 13 & Spring \\
\hline & $\begin{array}{l}\text { Yersinia enterocolitica (Schleifstein } \\
\text { \& Coleman) [25] }\end{array}$ & 1 & 10 & Spring \\
\hline Pasterurellaceae & Pasteurella multocida Pasteur [26] ${ }^{2}$ & 2 & 4,7 & Spring \\
\hline \multirow{2}{*}{ Vibrionaceae } & Vibrio cholerae Pacini [21] & 2 & 11,12 & Summer-Autumn \\
\hline & $\begin{array}{l}\text { Vibro parahemolyticus } \\
\text { Fujino et al./Sakazaki et al. [21] }\end{array}$ & 1 & 8.11 & Summer \\
\hline Moraxellaceae & $\begin{array}{c}\text { Acinetobacter lwoffii Brisou \& } \\
\text { Prévot [27] }\end{array}$ & 1 & 6 & Winter \\
\hline
\end{tabular}

${ }^{1}$ References of diarrhea (including diarrheic outbreaks) by the bacteria found in this study, linked to wastewater contamination to well water. ${ }^{2}$ Infection is linked to an infected animal exposure, but in bacteremia cases, $50 \%$ of patients reported no contact with animals [26]

The antibiotic susceptibility analysis to detect multidrug-resistant (MDR), extensively drug-resistant (XDR) or pandrug resistant (PDR) bacteria among enterobacteria isolates was performed using 21 different antibiotics. By a proposed definition, any strain presenting a resistance phenotype in $\geqslant 3$ classes of antibiotics is an MDR bacterium [28]. The breakpoint combo panel for each isolate showing lower inhibition by each exposed antibiotic is listed in Supplementary Material Table S1 [17,18]. Antibiotic resistance results are listed in Table 3 and Supplementary Material Tables S1 and S2. Accordingly to the resistance phenotype definition, we isolated five MDR bacteria: 2/4 bacteria were identified as K. oxytoca (77704370 and 77714372), 2/7 bacteria were identified as E. coli (77115010 and 77113010), and $1 / 3$ bacteria were identified as E. cloacae (77103173). The individual profiles of the single isolates showing resistance to at least one antibiotic revealed that Hafnia alvei exhibited intrinsic antibiotic resistance against either cefuroxime (biotype 43005103) or cefazolin (biotypes 43005103, 43005103 and 76103172). Similarly, Aeromonas hydrophila biotype 60010150 exhibited resistance against trimetroprim-sulfametoxazole and ampicillin-sulbactam, whereas Tatumella sp. (biotype 600000110) exhibited resistance against ampicillin or the ampicillin-sulbactam complex (Supplementary Table S2). 
Table 3. Identification of enterobacteria demonstrating antibiotic resistance using the AutoScan ID panel database. ${ }^{1}$

\begin{tabular}{|c|c|c|c|}
\hline Antimicrobial Category & Antimicrobial Agent & $\begin{array}{l}\text { Antimicrobial } \\
\text { Susceptibility }\end{array}$ & $\begin{array}{l}\text { Species with Intrinsic Resistance } \\
\text { to Antimicrobial Agents or } \\
\text { Categories (51)a }\end{array}$ \\
\hline \multirow{3}{*}{ Aminoglycosides } & Gentamicin & $\mathrm{S}$ & All isolates \\
\hline & Tobramycin & IR & Escherichia coli (1/7) (IR) \\
\hline & Amikacin & $\mathrm{R}$ & $\begin{array}{c}\text { Escherichia coli }(1 / 7) \\
\text { Klebsiella oxytoca }(1 / 4)(\mathrm{IR})\end{array}$ \\
\hline \multirow{2}{*}{$\begin{array}{l}\text { Antipseudomonal penicillin } \\
+\beta \text {-lactamase inhibitors }\end{array}$} & Ticarcillin-clavulanic acid & $\mathrm{R}$ & Escherichia coli (1/7) \\
\hline & $\begin{array}{l}\text { Piperacillin-tazobactam } \\
\text { (Pip/tazo) }\end{array}$ & $\mathrm{R}$ & $\begin{array}{c}\text { Enterobacter cloacae }(1 / 3) \\
\text { Escherichia coli }(1 / 7) \\
\text { Klebsiella oxytoca }(1 / 4)\end{array}$ \\
\hline \multirow[t]{2}{*}{ Carbapenems } & Imipenem & IR & $\begin{array}{l}\text { Klebsiella oxytoca (1/4) (IR) } \\
\text { Tatumella sp. }(1 / 1)(\mathrm{IR})\end{array}$ \\
\hline & Meropenem & $\mathrm{S}$ & All isolates \\
\hline \multirow{2}{*}{$\begin{array}{l}\text { Non-extended spectrum } \\
\text { Cephalosporin: 1st and 2nd } \\
\text { generation cephalosporins }\end{array}$} & Cefazolin & $\mathrm{R}$ & $\begin{array}{c}\text { Escherichia coli }(1 / 7) \\
\text { Escherichia coli }(1 / 7)(\mathrm{IR}) \\
\text { Klebsiella oxytoca }(2 / 4) \\
\text { Klebsiella oxytoca }(1 / 4)(\mathrm{IR}) \\
\text { Vibrio parahaemolyicus }(1 / 1) \\
\text { (Vibrionaceae) }\end{array}$ \\
\hline & Cefuroxime & $\mathrm{R}$ & $\begin{array}{c}\text { Enterobacter cloacae }(1 / 2) \\
\text { Escherichia coli }(1 / 7) \\
\text { Klebsiella oxytoca }(1 / 4) \\
\text { Klebsiella oxytoca }(1 / 4)(\mathrm{IR}) \\
\text { Vibrio parahaemolyicus }(1 / 1) \\
\text { (Vibrionaceae) }(\mathrm{IR})\end{array}$ \\
\hline \multirow{3}{*}{$\begin{array}{l}\text { Extended-spectrum } \\
\text { Cephalosporin: 3rd and 4th } \\
\text { generation cephalosporins }\end{array}$} & Cefotaxime or ceftriaxone & $\mathrm{R}$ & $\begin{array}{c}\text { Aeromonas hydrophila }(1 / 1)(\mathrm{IR}) \\
\text { Citrobacter freundii }(1 / 2)(\mathrm{IR}) \\
\text { Enterobacter cloacae }(1 / 3)(\mathrm{IR}) \\
\text { Escherichia coli }(1 / 7) \\
\text { Klebsiella oxytoca }(3 / 4) \\
\text { Salmonella enterica subsp. enterica, } \\
\text { serovar Paratyphi A }(1 / 2)\end{array}$ \\
\hline & Ceftazidime & $\mathrm{R}$ & $\begin{array}{c}\text { Citrobacter freundii }(1 / 2) \\
\text { Enterobacter cloacae }(1 / 3) \\
\text { Escherichia coli }(1 / 7)\end{array}$ \\
\hline & Cefepime & $\mathrm{R}$ & $\begin{array}{c}\text { Escherichia coli }(1 / 7) \\
\text { Enterobacter cloacae }(1 / 3) \\
\text { Klebsiella oxytoca }(1 / 4) \\
\text { Klebsiella oxytoca }(1 / 4)(\mathrm{IR}) \\
\end{array}$ \\
\hline Cephamycins & Cefotetan & $\mathrm{R}$ & Klebsiella oxytoca $(1 / 4)$ \\
\hline \multirow{3}{*}{ Fluoroquinolones } & Ciprofloxacin & $\mathrm{R}$ & $\begin{array}{c}\text { Escherichia coli (2/7) } \\
\text { Escherichia coli (1/7) (IR) } \\
\text { Klebsiella oxytoca (1/4) (IR) }\end{array}$ \\
\hline & Moxifloxacin & $\mathrm{R}$ & $\begin{array}{c}\text { Escherichia coli }(2 / 7) \\
\text { Escherichia coli }(1 / 7)(\mathrm{IR}) \\
\text { Klebsiella oxytoca (1/4) (IR) }\end{array}$ \\
\hline & Levofloxacin & $\mathrm{R}$ & $\begin{array}{c}\text { Escherichia coli }(2 / 7) \\
\text { Escherichia coli }(1 / 7)(\mathrm{IR}) \\
\text { Klebsiella oxytoca }(1 / 4) \\
\text { S. enterica subsp. enterica, serovar } \\
\text { Paratyphi A }(1 / 2)(\mathrm{IR})\end{array}$ \\
\hline Folate pathway inhibitors & Trimethoprim-sulfamethoxazole & $\mathrm{R}$ & $\begin{array}{c}\text { Aeromonas hydrophila }(1 / 1) \\
\text { Escherichia coli }(3 / 7)\end{array}$ \\
\hline
\end{tabular}


Table 3. Cont.

\begin{tabular}{|c|c|c|c|}
\hline Antimicrobial Category & Antimicrobial Agent & $\begin{array}{l}\text { Antimicrobial } \\
\text { Susceptibility }\end{array}$ & $\begin{array}{c}\text { Species with Intrinsic Resistance } \\
\text { to Antimicrobial Agents or } \\
\text { Categories (51)a }\end{array}$ \\
\hline Monobactams & Aztreonam & $\mathrm{R}$ & $\begin{array}{c}\text { Citrobacter freundii }(1 / 2)(\mathrm{IR}) \\
\text { Enterobacter cloacae }(1 / 2) \\
\text { Escherichia coli }(2 / 7) \\
\text { Klebsiella oxytoca }(1 / 4)\end{array}$ \\
\hline Penicillin & Ampicillin & $\mathrm{R}$ & $\begin{array}{c}\text { Escherichia coli }(2 / 7) \\
\text { S. enterica subsp. enterica, serovar } \\
\text { Paratyphi A }(1 / 2)(\mathrm{IR}) \\
\text { Shigella sp. }(1 / 1) \\
\text { Tatumella sp. }(1 / 1) \\
\text { Vibrio cholerae }(2 / 2) \text { (Vibrionaceae) }\end{array}$ \\
\hline $\begin{array}{l}\text { Penicillin }+\beta \text {-lactamase } \\
\text { inhibitors }\end{array}$ & Ampicillin-sulbactam & $\mathrm{R}$ & $\begin{array}{c}\text { Aeromonas hydrophila }(1 / 1) \\
\text { Enterobacter cloacae }(1 / 3) \\
\text { Escherichia coli }(2 / 7) \\
\text { Hafnia alvei }(2 / 3)(\mathrm{IR}) \\
\text { Klebsiella oxytoca }(1 / 4) \\
\text { Shigella sp. }(1 / 1) \\
\text { Tatumella sp. }(1 / 1)\end{array}$ \\
\hline
\end{tabular}

\footnotetext{
${ }^{1}$ Enterobacteria were isolated from samples collected during 2013 at Bassaseachic Falls National park, Ocampo, Chihuahua, Mexico. See information regarding the biotypes in Supplementary Table S2. Antimicrobial categories: $\mathrm{R}=$ resistant; $\mathrm{S}=$ susceptible; $\mathrm{IR}=$ Intermediate resistance.
}

An evaluation of the antibiotic resistance of the antibiotic tested revealed that all 33 isolates were susceptible to gentamicin, imipenem, meropenem and tobramycin. In addition, 3\% to $6.1 \%$ of the isolates presented intermediate resistance to most other antimicrobials tested, including imipenem and tobramycin (Figure 4, Supplementary Table S2).

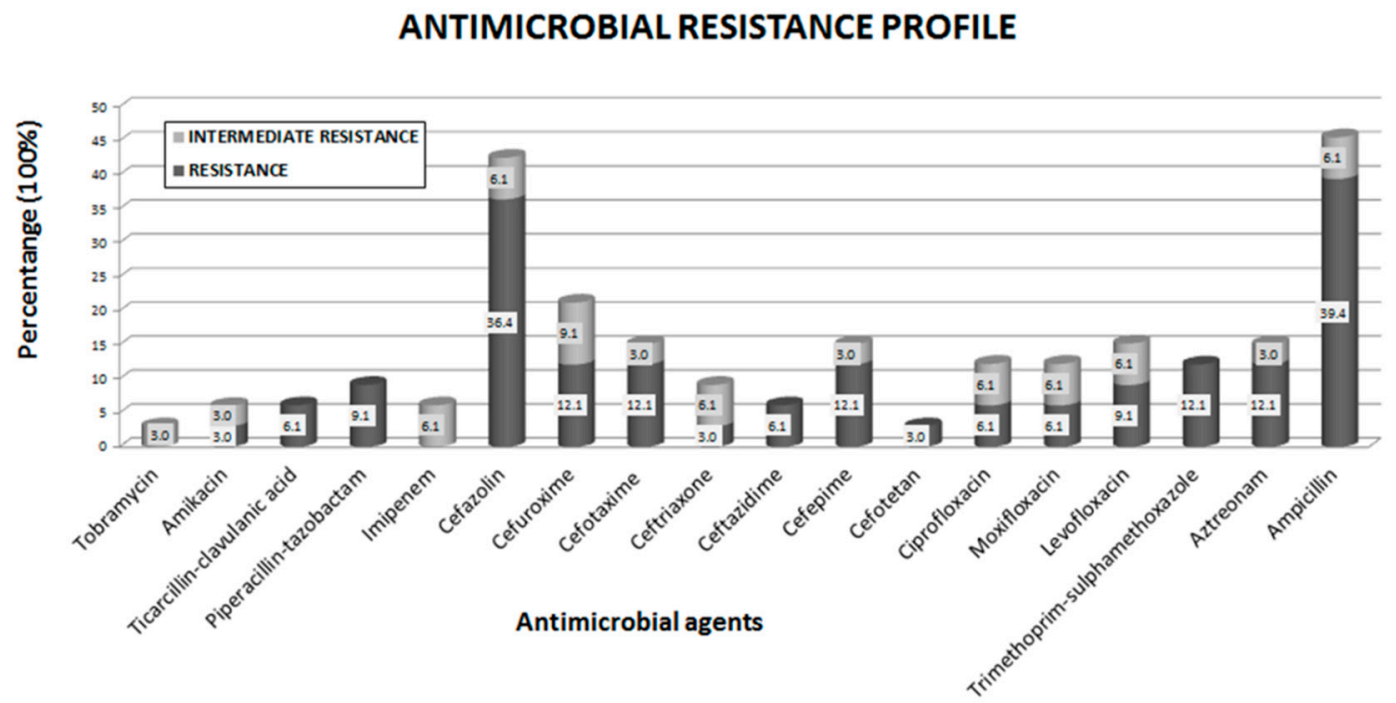

Figure 4. Antibiotic resistance profiles (\%) among the isolates from samples collected during 2013 and sampling sites in the Bassaseachic Falls National park, Ocampo, Chihuahua, Mexico, using the AutoScan ID panel database.

Additionally, $39.4 \%$ of isolates were resistant to ampicillin; $36.4 \%$ of isolates were resistant to cefazoline; $21.2 \%$ of isolates were resistant to ampicillin-sulbactam; $12.1 \%$ of isolates were resistant to aztreonam, cefepime, cefotaxima, cefuroxima and trimethoprim-sulfamethoxazole; $9.1 \%$ of isolates were resistant to levofloxacin and piperacillin-tazobactam; and $6.1 \%$ of isolates were resistant to ceftazidime, ciprofloxacin, moxifloxacin and ticacillin-clavulanic acid. Only $3 \%$ of isolates were resistant to amikacin, cefotetan and ceftriaxone. In the present study, Tatumella sp. did not exhibit 
resistance to any antibiotic tested; however, this bacterium exhibited intermediate resistance to imipenem, similar to the K. oxytoca isolate. In the present study, we identified one E. coli isolate exhibiting intermediate resistance to tobramycin (Supplementary Table S2). The antibiotic resistance profiles comparing freshwater native and enterobacterial species/biotypes collected at Basaseachi river revealed intermediate resistance in $48 \%(16 / 33)$ of all isolates detected in the present study (Supplementary Table S2).

\section{Discussion}

Basaseachi river and waterfalls is the second-highest waterfall (807 feet tall) in Mexico and is located in the Bassaseachic Falls National Park at Cañon Basaseachi in the Copper Canyon region of northwest Mexico, near Creel, Chihuahua. Diarrheic outbreaks have been observed among inhabitants of this area, whom lack to access to non-contaminated water and appropriate sewage disposal. Unfortunately, clinical official data are not available due to ill inhabitants' poverty and deficiencies in sample analyses. Moreover, medical facilities are insufficient and conventional antibiotic treatments are not quite effective to control the diarrhea symptoms. As a result, most ill people with acute diarrhea must go to other closer hospitals to get proper medical attention, being more difficult to get clinical data of Basaseachi inhabitants. These diarrheic outbreaks have prompted to evaluate the water contamination, looking after responsible microorganisms that may be related to this outbreak event, and if those microorganisms are resistant to the recommended antibiotics for diarrhea medical control (project approved by the National Commission of Protected Natural Areas CONANP/DR03/08/PN01/PROCODES/1259/13). The aim of the present study was to identify the populations and antibiotic resistance profiles of coliforms present in the Basaseachi river and streams within the park to detect microbial contamination that may be resistant to conventional drug treatments. The samples were collected near rural settlements, including the waterfall well and the belvedere of Bassaseachic Falls National Park.

Mexican standard regulations established a limit of 1000 MPN/100 mL (3.5 MPN) fecal coliforms from sewage pollutants dumped in natural environments [19]. After analyzing the total coliform populations among the seasons, the highest population was detected during rainfall in the summer of 2013 (Figure 3A). For fecal coliform counts, autumn exhibited the highest value among the seasons of the year (Figure 3C). The results may indicate water movement during rain and higher temperatures (above $35^{\circ} \mathrm{C}$ in daylight) during summer. In contrast, the lowest total coliform counts were observed in summer and winter as lower rain/humidity and temperatures (not higher than $20^{\circ} \mathrm{C}$ ) are present (Figure 3C). Davino et al. [29] reported similar results after analyzing the coliform counts in Jatiúca Beach, Brazil. These authors reported that the fecal coliform count was higher during the wet seasons (May, June, and July) than during the dry seasons (November, December, and January).

Analysis of the data for total and fecal coliform enumerations at the sampling sites revealed that, except for sampling sites 9, 10, and 12, the collected samples possessed more than $1000 \mathrm{MPN} / 100 \mathrm{~mL}$ (3.5 MPN) fecal coliforms during the autumn and summer seasons (Figure 2A,B). Samples 6 and 8 were collected near the biggest rural settlements, and sample 11 was obtained from an oxidation lagoon that might be filtered into the Bassaseachic Falls National Park River. Sample 9, which exhibited the lowest coliform count, was collected from a rural settlement belonging to the park keepers and inhabited by approximately 20 people. This site was likely associated with lower sanitary discharges and fecal pollution (Figure 2A,B).

A total of 33 Gram negative isolates showing macroscopic and microscopic differences (gamma-proteobacteria) were selected to identify enterobacteria populations present in the Bassaseachic Falls National Park River. Biochemical identification analyses grouped them in 16 different genera and species from the Enterobacteriaceae, Pasterurellaceae, Vibrionaceae, and Moraxellaceae families (Table 2). Selected isolates identified in the present study are commonly reported in epidemic water outbreaks in developing countries $[4,9,30]$, thereby explaining the diarrhea outbreaks observed among the Basaseachi waterfalls inhabitants, primarily the children. Gastrointestinal diseases were associated 
with most bacterial pathogens found in this study, and linked with wastewater contamination to well water (Table 2). The identified genera included Escherichia, a fecal indicator of polluted waters [31]. Furthermore, the presence of Shigella sp., a strictly human pathogen, may also be associated with human fecal pollution [32]. Bacterial pathogens are considered water pollutants (biological contaminants) due to the run-off from urban and agricultural areas, leakage from sewers and septic systems, and sewer overflows [33]. The presence of Salmonella sp. in food and water is considered a Public Health risk, since such as bacterium is not a common water inhabitant [34].

Salmonella is the most frequent causative agent of bacterial gastroenteritis [34,35]. It is difficult to isolate from environmental water samples; nevertheless, the presence of Salmonella represents a Public Health risk as the infective dose can be as low as 15 to 100 bacterial cells per milliliter [34]. Furthermore, chicken is a major vehicle for the transmission of this bacterium, which is considered a major problem in the poultry industry [35]. The chicken poultry breeding is a common practice within the Basaseachi river inhabitants.

In addition, Yersinia has been associated with seafood contamination and water outbreaks, whereas E. coli $\mathrm{O} 157: \mathrm{H7}$, frequently isolated from waters worldwide, has been identified in $2 \%$ of raw sludge [32]. Multidrug resistance patterns have been also detected in $E$. coli isolates isolated from river water in Osun State, Nigeria [36] and from the holy city of Mathura, India [37].

Nevertheless, seven of our enterobacterial isolates are rarely pathogens, but they were observed in nosocomial infections, mostly among immunosuppressed patients [21]. Diseases related with these less common enteropathogens include acute diarrheas, gastroenteritis, septicemia, meningitis, and wound infections by A. hydrophila [20,21]; diarrhea by $C$. freundii (after having or acquiring the ability to produce an enterotoxin) [21,22]; community-acquired and nosocomial infections such as urinary tract infections and bacteremia by E. cloacae [21]; acute diarrhea and Traveler's diarrhea by Hafnia alvei [38]; nosocomial intestinal and urinal infections by K. oxytoca [21]; gastroenteritis by Tatumella sp. [24]; and gastritis, cellulitis, endocarditis, endophthalmitis by A. lwoffii [27]. The only isolated bacterium that has not been associated with water contamination, but by an infected animal direct contact is P. multocida. Nevertheless, in a 30-year study, the Detroit Medical Center observed this bacterium causing infections in 14 patients, half of which reported no contact with animals [26].

As stated before, Klebsiella members are opportunistic nosocomial pathogens; only K. pneumoniae and $K$. oxytoca are human pathogens. Hospital outbreaks frequently result from a new strain type of multidrug-resistant Klebsiella sp. Among the environmental water samples, the number of Klebsiella spp. was low (usually one to five colony-forming units [CFU]/250 mL), regardless of season. Podschun et al. [39] reported that among the Klebsiella sp. isolated, K. pneumoniae was the most common $(52 \%)$, followed by K. oxytoca (27\%). In the present study, the K. oxytoca population was higher (four isolates) compared with the K. pneumoniae population (one isolate). In addition, $50 \%$ of the K. oxytoca isolates $(2 / 4)$ were identified as multidrug-resistant bacteria.

As previously described, after two or more isolates from the same sampling point were identified as identical (same biotype flinging number), only one isolate was selected for further analyses. Seven of 33 isolates total were identified with the same biotype, thus suggesting they were similar strains; however, these strains were isolated from different sample points and did not present the same resistance profile [1,40].

A. lwoffi-like species are commonly isolated from pelletized food, and A. hydrophila has been associated with fish disease [20,41], whereas the Tatumella sp. [42] has been associated with soil inhabitants [43]. Similarly, H. alvei has been isolated from mammals, birds, reptiles, fish, soil, water, and sewage samples. These enteric bacteria are considered non-human-associated bacteria and rare opportunistic pathogens [38]. A. lwoffii, A. hydrophila, and Tatumella sp. are saprophyte bacteria. In the wild, these microbes are not considered human health risk bacteria $[7,44]$.

In the present study, we evaluated the antibiotic susceptibility of 33 selected enterobacterial isolates from the collected freshwater samples to identify bacteria considered as Public Health threats by showing multidrug resistance patterns. According to the international standard definitions for any 
MDR microorganism [28], we isolated five MDR bacteria; two isolates were identified as K. oxytoca, two as E. coli, and one as E. cloacae. Nevertheless, same genera and species isolates were identified, representing the $50 \%(2 / 4)$ the MDR isolates identified as K. oxytoca, $28.57 \%(2 / 7)$, the MDR isolates identified as E. coli and $33.33 \%(1 / 3)$ the MDR isolate identified as E. cloacae. This pattern of resistance to several key antibiotics commonly used in therapeutic treatments is considered a public health threat [28]. Similarly, MDR isolates from the Enterobacteriaceae family have been identified in the Almendares River in Cuba [45]. As mentioned above, from 33 isolates, seven presented a similar biotype; however, identical isolates did not possess the same resistance profile, thus indicating a potential antibiotic resistance selection $[1,40,44]$.

Active antibiotics can be discharged in considerable amounts in the forms of human waste. Native bacteria in natural environments can be exposed to these antibiotics, particularly those with higher persistence in the environment, such as fluoroquinolones and tetracyclines. Fluoroquinolones and tetracyclines are more stable and remain in the environment for longer periods of time, facilitating bacterial antibiotic resistance selection [46]. The increasing rate of antibiotic-resistant microorganisms is recognized as a serious ecological problem [47].

Overall, the results of the present study demonstrated that the antibiotic resistance patterns detected in the isolates collected from Bassaseachic Falls National Park, may be the reason for the ineffective control using antibiotics to control gastrointestinal infections, resulting in lower alternatives for therapeutic treatments. Some of the identified bacteria in the present study were coliforms/enteropathogenic species, thus indicating a human or animal waste source. Animal and human waste, mostly generated in rural locations, is discharged into water bodies, and play an important role in diarrhea outbreaks observed within inhabitants of this northwest Mexican area.

\section{Conclusions}

Surface water samples from Bassaseachic Falls National Park revealed the presence of bacterial pathogens that are considered public health risks. Five isolates showing multidrug (antibiotic) resistance (MDR) profiles from this natural water environment were identified. Overall, the microorganisms detected may cause future problems and represent a health threat to the people who live near this park. MDR agents constitute a major threat to Public Health and should receive more attention. The monitoring of antibiotics resistance genes and the presence of resistant bacteria in the environment are increasingly viewed as ecological problems for which further studies are needed to provide solutions that preserve seasonal water bodies, such as ponds, rivers, lakes, and waterfalls, and their productive ecosystems.

Supplementary Materials: The following are available online at www.mdpi.com/1660-4601/13/6/597/s1, Figure S1: Diagram of the microbiology analysis flux, Table S1: Interpretative breakpoints, Table S2: Native and enterobacterial species/biotypes isolated from freshwater samples collected from the Bassaseachic National Park, México.

Acknowledgments: This project was financially supported through grants from the Laboratorio de Inmunología y Virología, in Facultad de Ciencias Biológicas at Universidad Autónoma de Nuevo León, México (DEMI-FCB-UANL), and Consejo Nacional de Ciencia y Tecnología (CONACyT) (scholarship to MCEDG and project CB2010/155771 to PTG), Universidad Autónoma de Chihuahua (UACH) and Comisión Nacional de Áreas Naturales Protegidas (CONANP) (project CONANP/DR03/08/PN01/PROCODES/1259/13) to RIR. The authors would like to thank Noé Ortega Corral and Guillermo Delgado Gardea from the University of Texas at El Paso (UTEP) for technical advice and Blanca Alanis Rodríguez and Alan Muñoz Payán for technical support.

Author Contributions: Ma. Carmen E. Delgado-Gardea carried out the biological analysis, worked on the microbiology characterization and drafted the manuscript, Patricia Tamez-Guerra participated in the design of the study, and drafted the manuscript, Ricardo Gómez-Flores characterized the community of microorganisms and worked on the manuscript, Francisco Javier Zavala-Díaz De La Serna participated in the design of sampling sites, Gilberto Erosa-de La Vega participated on the characterization of multidrug resistance bacteria, Guadalupe Virgina Nevárez-Moorillón participated in the design of the study, performed statistical analysis and worked on the manuscript, Blanca Sánchez-Ramírez and María Del Carmen González-Horta participated on the biological activity, María Concepción Pérez-Recoder facilitate field installations as representative of CONANP and Rocío Infante-Ramírez conceived the study, worker on data analysis and worked on the manuscript.

Conflicts of Interest: The authors declare that there are no conflict of interest. 


\section{References}

1. Baquero, F.; Martínez, J.L.; Cantón, R. Antibiotics and antibiotic resistance in water environments. Curr. Opin. Biotechnol. 2008, 19, 260-265. [CrossRef] [PubMed]

2. Korzeniewska, E.; Korzeniewska, A.; Harnisz, M. Antibiotic resistant Escherichia coli in hospital and municipal sewage and their emission to the environment. Ecotoxicol. Environ. Saf. 2013, 91, 96-102. [CrossRef] [PubMed]

3. Figueras, M.J.; Borrego, J.J. New perspectives in monitoring drinking water microbial quality. Int. J. Environ. Res. Public Health 2010, 7, 4179-4202. [CrossRef] [PubMed]

4. Ashbolt, N.J. Microbial contamination of drinking water and disease outcomes in developing regions. Toxicology 2004, 198, 229-238. [CrossRef] [PubMed]

5. World Health Organization. Diarrhoeal Disease Fact Sheet. Available online: http://www.who.int/ mediacentre/factsheets/fs330/en/ (accessed on 31 March 2016).

6. Amdiouni, H.; Maunula, L.; Hajjami, K.; Faouzi, A.; Soukri, A.; Nourlil, J. Recovery comparison of two virus concentration methods from wastewater using cell culture and real-time PCR. Curr. Microbiol. 2012, 65, 432-437. [CrossRef] [PubMed]

7. Edqvist, L.; Pedersen, K. Antimicrobials as growth promoters: Resistance to common sense. In Late Lessons from Early Warnings: The Precautionaryprinciple 1896-2000; Harremoës, P., Gee, D., MacGarvin, M., Stirling, A., Keys, J., Wynne, B., Guedes Vaz, S., Eds.; European Environmental Agency: Copenhagen, Denmark, 2001; pp. 93-100.

8. Brown, M.G.; Balkwill, D.L. Antibiotic resistance in bacteria isolated from the deep terrestrial subsurface. Microb. Ecol. 2009, 57, 484-493. [CrossRef] [PubMed]

9. Gesche, E.; Vallejos, A.; Sáez, M. Eficiencia de anaerobios sulfito-reductores como indicadores de calidad sanitaria de agua. Método de Número Más Probable (NMP). Arch. Med. Vet. 2003, 35, 99-107. [CrossRef]

10. Bush, K.; Courvalin, P.; Dantas, G.; Davies, J.; Eisenstein, B.; Huovinen, P.; Jacoby, G.A.; Kishony, R.; Kreiswirth, B.N.; Kutter, E.; et al. Tackling antibiotic resistance. Nat. Rev. Microbiol. 2011, 9, 894-896. [CrossRef] [PubMed]

11. Port, J.A.; Cullen, A.C.; Wallace, J.C.; Smith, M.N.; Faustman, E.M. Metagenomic frameworks for monitoring antibiotic resistance in aquatic environments. Environ. Health Perspect. 2014, 122, 222-228. [CrossRef] [PubMed]

12. Munir, M.; Wong, K.; Xagoraraki, I. Release of antibiotic resistant bacteria and genes in the effluent and biosolids of five wastewater utilities in Michigan. Water Res. 2011, 45, 681-693. [CrossRef] [PubMed]

13. Diario Oficial de la Federación (1994). NOM-014-SSA1-1993. Procedimientos Sanitarios para el Muestreo de Agua para uso y Consumo Humano en Sistemas de Abastecimiento de Agua Públicos y Privados. Secretaría de Salud. México, D.F. Available online: http://www.salud.gob.mx/unidades/cdi/nom/127ssa14.html (accessed on 14 June 2016).

14. Diario Oficial de la Federación (2005). Proyecto PROY-NMX-AA-042-SCFI-2005. Calidad del Agua.-Determinación del Número más Probable (NMP) de Coliformes Totales, Coliformes Fecales (Termotolerantes) y Escherichia coli Presuntiva (Cancelará a la NMX-AA-042-1987). México, D.F. Available online: http://legismex.mty.itesm.mx/normas/aa/nmx-AA-05/proy-nmx-aa-042-scfi-2005.pdf (accessed on 14 June 2016).

15. Al-Bayatti, K.K.; Al-Arajy, K.H.; Al-Nuaemy, S.H. Bacteriological and physicochemical studies on Tigris River near the water purification stations within Baghdad Province. J. Environ. Public Health 2012, 2012, 695253. [CrossRef] [PubMed]

16. Rhodes, J.B.; Smith, H.L.; Ogg, J.E. Isolation of non-O1 Vibrio cholerae serovars from surface waters in western Colorado. Appl. Environ. Microbiol. 1986, 51, 1216-1219. [PubMed]

17. Clinical and Laboratory Standards Institute. Methods for Dilution Antimicrobial Susceptibility Tests for Bacteria that Grow Aerobically. Approved Standard. CLSI document M07-A10; Wayne, PA, USA, 2015, 10th ed. Available online: http://shop.clsi.org/site/Sample_pdf/M07A10_sample.pdf (accessed on 31 March 2016).

18. Clinical and Laboratory Standards Institute. Performance Standards for Antimicrobial Susceptibility Testing. CLSI Document M100-S24; Wayne, PA, USA, 2014. Available online: http://ncipd.org/control/images/ NCIPD_docs/CLSI_M100-S24.pdf (accessed on 31 March 2016). 
19. Diario Oficial de la Federación. (1997) DOF-001-ECOL-1996, que Establece los Límites Máximos Permisibles de Contaminantes en las Descargas de Aguas Residuales a los Sistemas en Aguas y Bienes Nacionales. Gobierno Constitucional de los Estados Unidos Mexicanos. México D.F. Available online: http:/ /dof.gob. $\mathrm{mx} /$ nota_detalle.php?codigo=4863829\&fecha=06/01/1997 (accessed on 14 June 2016).

20. Agger, W.A.; McCormick, J.D.; Gurwith, M.J. Clinical and microbiological features of Aeromonas hydrophila-associated diarrhea. J. Clin. Microbiol. 1985, 21, 909-913. [PubMed]

21. Cabral, J.P. Water microbiology. Bacterial pathogens and water. Int. J. Environ. Res. Public Health 2010, 7, 3657-3703. [CrossRef] [PubMed]

22. Abbott, S.L.; Janda, J.M. Revisiting bacterial gastroenteritis: Issues, possible approaches, and an ever-expanding list of etiologic agents, Part II. Clin. Microbiol. Newslett. 2011, 33, 79-86. [CrossRef]

23. Threlfall, E.J. Antimicrobial drug resistance in Salmonella: Problems and perspectives in food- and water-borne infections. FEMS Microbiol. Rev. 2002, 26, 141-148. [CrossRef] [PubMed]

24. Janda, J.M.; Abbot, S.L. Uncommon enterobacterial genera associated with clinical specimens. In The Enterobacteria, 2nd ed.; American Society Microbiology: Washington, DC, USA, 2006; pp. 357-375.

25. Thompson, J.S.; Gravel, M.J. Family outbreak of gastroenteritis due to Yersinia enterocolitica serotype 0:3 from well water. Can. J. Microbiol. 1986, 32, 700-701. [CrossRef] [PubMed]

26. Poblete, J. Pasteurella multocida bacteremia: Concern remains even in the absence of direct animal contact. Inf. Dis. Clin. Pract. 2009, 17, 77. [CrossRef]

27. Heéger, Z.; Vargha, M.; Márialigeti, K. Detection of potentially pathogenic bacteria in the drinking water distribution system of a hospital in Hungary. Clin. Microbiol. Infect. 2010, 16, 89-92. [CrossRef]

28. Magiorakos, A.P.; Srinivasan, A.; Carey, R.B.; Carmeli, Y.; Falagas, M.E.; Giske, C.G.; Harbarth, S.; Hindler, J.F.; Kahlmeter, G.; Olsson-Liljequist, B.; et al. Multidrug-resistant, extensively drug-resistant and pandrug-resistant bacteria: An international expert proposal for interim standard definitions for acquired resistance. Clin. Microbiol. Infect. 2012, 18, 268-281. [CrossRef] [PubMed]

29. Davino, A.M.; Melo, M.B.; Caffaro Filho, R.A. Assessing the sources of high fecal coliform levels at an urban tropical beach. Braz. J. Microbiol. 2015, 46, 1019-1026. [CrossRef] [PubMed]

30. Hassan, K.E.; Mansour, A.; Shaheen, H.; Amine, M.; Riddle, M.S.; Young, S.Y.; Sebeny, P.; Levin, S. The impact of household hygiene on the risk of bacterial diarrhea among Egyptian children in rural areas, 2004-2007. J. Infect. Dev. Countr. 2014, 8, 1541-1551. [CrossRef] [PubMed]

31. Payment, P.; Locas, A. Pathogens in water: Value and limits of correlation with microbial indicators. Ground Water 2011, 49, 4-11. [CrossRef] [PubMed]

32. Van den Bogaard, A.E.; Stobberingh, E.E. Epidemiology of resistance to antibiotics. Links between animals and humans. Int. J. Antimicrob. Agents 2000, 14, 327-335. [CrossRef]

33. Girones, R.; Ferrús, M.A.; Alonso, J.L.; Rodriguez-Manzano, J.; Calgua, B.; de Abreu Corrêa, A.; Hundesa, A.; Carratala, A.; Bofill-Mas, S. Molecular detection of pathogens in water-The pros and cons of molecular techniques. Water Res. 2010, 44, 4325-4339. [CrossRef] [PubMed]

34. Sidhu, J.P.; Toze, S.G. Human pathogens and their indicators in biosolids: A literature review. Environ. Int. 2009, 35, 187-201. [CrossRef] [PubMed]

35. Grant, A.; Hashem, F.; Parveen, S. Salmonella and Campylobacter: Antimicrobial resistance and bacteriophage control in poultry. Food Microbiol. 2016, 53, 104-109. [CrossRef] [PubMed]

36. Titilawo, Y.; Obi, L.; Okoh, A. Occurrence of virulence gene signatures associated with diarrhoeagenic and non-diarrhoeagenic pathovars of Escherichia coli isolates from some selected rivers in South-Western Nigeria. BMC Microbiol. 2015, 15, 204. [CrossRef] [PubMed]

37. Amit, A.; Kumar, A.; Kumar, M.; Rahal, A. Multidrug resistant pathogenic Escherichia coli status in water sources and Yamuna River in and around Mathura, India. Pak. J. Biol. Sci. 2014, 17, 540-544. [CrossRef]

38. Miranda, C.D.; Zemelman, R. Antimicrobial multiresistance in bacteria isolated from freshwater Chilean salmon farms. Sci. Total Environ. 2002, 293, 207-218. [CrossRef]

39. Podschun, R.; Pietsch, S.; Höller, C.; Ullmann, U. Incidence of klebsiella species in surface waters and their expression of virulence factors. Appl. Environ. Microbiol. 2001, 67, 3325-3327. [CrossRef] [PubMed]

40. Sayah, R.S.; Kaneene, J.B.; Johnson, Y.; Miller, R. Patterns of antimicrobial resistance observed in Escherichia coli isolates obtained from domestic- and wild-animal fecal samples, human septage, and surface water. Appl. Environ. Microbiol. 2005, 71, 1394-1404. [CrossRef] [PubMed] 
41. Debarry, J.; Garn, H.; Hanuszkiewicz, A.; Dickgreber, N.; Blümer, N.; von Mutius, E.; Bufe, A.; Gatermann, S.; Renz, H.; Holst, O.; et al. Acinetobacter lwoffii and Lactococcus lactis strains isolated from farm cowsheds possess strong allergy-protective properties. J. Allergy Clin. Immunol. 2007, 119, 1514-1521. [CrossRef] [PubMed]

42. Hollis, D.G.; Hickman, F.W.; Fanning, G.R.; Farmer, J.J., III; Weaver, R.E.; Brenner, D.J. Tatumella ptyseos gen. nov., sp. nov., A member of the family Enterobacteriaceae found in clinical specimens. J. Clin. Microbiol. 1981, 14, 79-88. [PubMed]

43. Toranzos, G.; Marcos, R. Human enteric pathogens and soil borne-disease. In Soil Biochemistry; Bollag, J.-M., Stotzky, G., Eds.; Marcel Dekker: New York, NY, USA, 2000; pp. 461-481.

44. Kellfy, B.G.; Vespermann, A.; Bolton, D.J. Gene transfer events and their occurrence in selected environments. Food Chem. Toxicol. 2009, 47, 978-983. [CrossRef] [PubMed]

45. Graham, D.W.; Olivares-Rieumont, S.; Knapp, C.W.; Lima, L.; Werner, D.; Bowen, E. Antibiotic resistance gene abundances associated with waste discharges to the Almendares River near Havana, Cuba. Environ. Sci. Technol. 2011, 45, 418-424. [CrossRef] [PubMed]

46. Larsson, D.G. Antibiotics in the environment. Upsala J. Med. Sci. 2014, 119, 108-112. [CrossRef] [PubMed]

47. Iliev, I.; Marhova, M.; Gochev, V.; Tsankova, M.; Trifonova, S. Antibiotic resistance of Gram-negative benthic bacteria isolated from the sediments of Kardzhali Dam (Bulgaria). Biotechnol. Biotechnol. Equip. 2015, 29, 274-280. [CrossRef] [PubMed]

(C) 2016 by the authors; licensee MDPI, Basel, Switzerland. This article is an open access article distributed under the terms and conditions of the Creative Commons Attribution (CC-BY) license (http://creativecommons.org/licenses/by/4.0/). 